\title{
Late sacroiliac fracture fixation implant-related infection through haematogenous spread
}

\author{
Conor S O'Driscoll (ㄷ, Andrew J Hughes, Brendan J O'Daly
}

National Pelvic and Acetabular Unit, Tallaght University Hospital, Dublin, Ireland

\section{Correspondence to} Dr Conor S O'Driscoll: coodrisc@tcd.ie

Accepted 22 August 2021
Check for updates

(c) BMJ Publishing Group Limited 2021. No commercial re-use. See rights and permissions. Published by BMJ.

\begin{tabular}{l}
\hline To cite: O'Driscoll CS, \\
Hughes AJ, O'Daly BJ. BMJ \\
Case Rep 2021;14:e245364. \\
doi:10.1136/bcr-2021- \\
245364
\end{tabular}

\section{DESCRIPTION}

A female in her 40s was referred to our institution having undergone right-sided percutaneous sacroiliac (SI) screw fixation of a pelvic fracture 28 years prior, following a road traffic collision. She had made a complete recovery and was engaging in an active lifestyle. She presented to her local primary care physician with non-specific symptoms of fevers and chills. A urinary tract infection was diagnosed, and the patient was treated empirically with antibiotics to which she responded.

However, over the following months, she reported an insidious onset of right-sided pelvic pain, both on weightbearing and while lying at night. On clinical examination, she exhibited tenderness at the site of her previous scar over the lateral part of iliac wing and tested positive for Flexion ABduction External Rotation test. She was then referred to the regional orthopaedic department for further investigation.

Initial workup consisted of a pelvic X-ray, demonstrating the SI screws in situ (figure 1), and laboratory investigations, which showed leucocytosis, neutrophilia and elevated inflammatory markers, including a $\mathrm{C}$ reactive protein (CRP) of 106 . The patient proceeded for an MRI of the pelvis which reported a right SI joint septic arthritis and osteomyelitis predominantly involving the iliac margin of the SI joint and an evolving abscess within the right piriformis muscle (figure 2). No growth was demonstrated on repeated blood cultures.

The patient was transferred to our institution which is a national pelvic orthopaedic centre. Following consultation with the patient, the

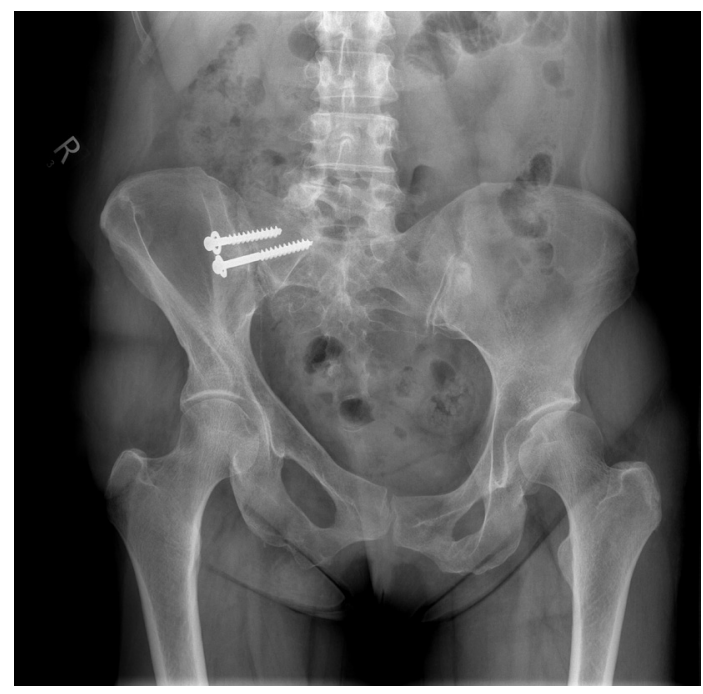

Figure 1 X-ray of pelvis: patient status after past screw fixation of the right sacroiliac joint.

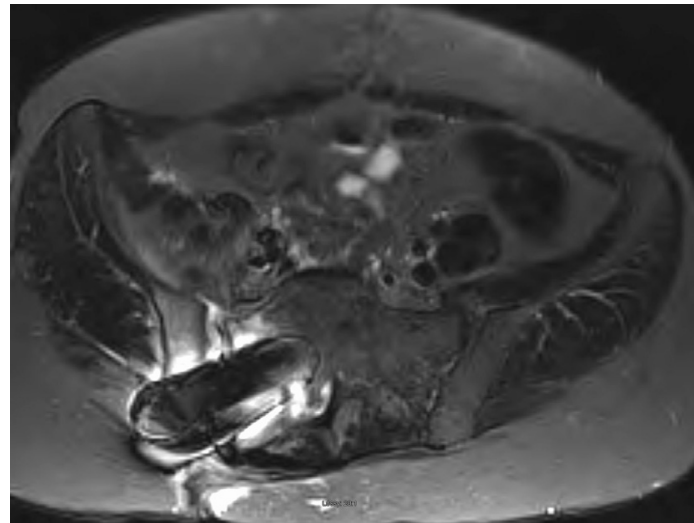

Figure 2 MRI of the pelvis: T2-weighted inversion recovery pulse sequence, axial: high signal change and increased fluid within the right sacroiliac joint, allowing for metallic artefact in keeping with septic arthritis and osteomyelitis.

decision was made to proceed for surgical removal of screws, to reduce the bacterial burden and obtain samples to guide microbiological therapy. Surgical removal was accompanied by curettage and debridement of the screw tract. There were nil intraoperative complications, and extended incubation of the screw sample displayed growth of the gramnegative rod Pseudomonas aeruginosa, which was piperacillin/tazobactam and ciprofloxacin sensitive.

The patient proceeded to make a full recovery following completion of an antibiotic regimen, consisting of 1 week of intravenous piperacillin/ tazobactam, followed by 6 weeks of oral ciprofloxacin. Clinically she returned to normal levels of activity and reported a cessation of pain. Laboratory follow-up, 3 months later, showed a normalisation of CRP to 2.

Deep implant-related infection is a serious complication of orthopaedic surgery with high related morbidity and mortality. Presentation symptoms are often subtle and may include

\section{Patient's perspective}

I am happy to report that 6 months on I am feeling well, with no further back or pelvic pain. I was delighted to return to walking and my other hobbies. Unfortunately, I suffered an unrelated injury to my shoulder which has me recuperating at present, but I am looking forward to getting back outside, once the current COVID-19 restrictions ease. 
stress-dependent pain, compromised functionality or sinus tract formation. Typical management consists of debridement and implant removal to reduce the bacterial burden and antibiotic therapy guided by samples. ${ }^{1}$

The causative organism in our case was $P$. aeruginosa. This is a gram-negative rod typically associated with nosocomial infections of the respiratory and urinary tracts, ${ }^{2}$ which displays a predilection towards biofilm formation. This contributes towards its pathogenicity, reducing bacterial efficacy, ${ }^{3}$ and often mandates the physical removal of metallic implants. ${ }^{4}$ Implantrelated infections most commonly occur early following fracture fixation; however, in rare cases, late infections may occur via haematogenous seeding. ${ }^{5}$ It is thus worth considering implant

\section{Learning points}

- Quiescent metalwork may, in the setting of acute bacterial infection, become a site of bacterial seeding

- In such cases, removal of metalwork reduces bacterial burden, halts the spread of osteomyelitis, guides antibiotic therapy via culture and sensitivity, and serves to facilitate a full recovery following completion of the appropriate microbiological treatment course infection as part of the differential for clinicians when investigating patients with localised pain and symptoms at the site of previous fracture fixation.

Contributors COD performed background research and drafted the paper. He is the guarantor. AH and BOD were involved in concept design and paper revision.

Funding The authors have not declared a specific grant for this research from any funding agency in the public, commercial or not-for-profit sectors.

Competing interests None declared.

Patient consent for publication Obtained.

Provenance and peer review Not commissioned; externally peer reviewed.

\section{ORCID iD}

Conor S O'Driscoll http://orcid.org/0000-0002-4828-5258

\section{REFERENCES}

1 Metsemakers WJ, Kuehl R, Moriarty TF, et al. Infection after fracture fixation: current surgical and microbiological concepts. Injury 2018;49:511-22.

2 Sharma G, Rao S, Bansal A, et al. Pseudomonas aeruginosa biofilm: potential therapeutic targets. Biologicals 2014;42:1-7.

3 Drenkard E. Antimicrobial resistance of Pseudomonas aeruginosa biofilms. Microbes Infect 2003:5:1213-9.

4 Ribeiro M, Monteiro FJ, Ferraz MP. Infection of orthopedic implants with emphasis on bacterial adhesion process and techniques used in studying bacterial-material interactions. Biomatter 2012;2:176-94.

5 Zimmerli W. Clinical presentation and treatment of orthopaedic implant-associated infection. J Intern Med 2014;276:111-9.

Copyright 2021 BMJ Publishing Group. All rights reserved. For permission to reuse any of this content visit

https://www.bmj.com/company/products-services/rights-and-licensing/permissions/

BMJ Case Report Fellows may re-use this article for personal use and teaching without any further permission.

Become a Fellow of BMJ Case Reports today and you can:

- Submit as many cases as you like

- Enjoy fast sympathetic peer review and rapid publication of accepted articles

- Access all the published articles

Re-use any of the published material for personal use and teaching without further permission

Customer Service

If you have any further queries about your subscription, please contact our customer services team on +44 (0) 2071111105 or via email at support@bmj.com.

Visit casereports.bmj.com for more articles like this and to become a Fellow 